\title{
Dasatinib-Related Chylothorax
}

\section{Dasatinib İlişkili Şilotoraks}

\author{
Yen-Min Huangl,2, Cheng-Hsu Wangl,3, Jen-Seng Huangl, Kun-Yun Yeh ${ }^{1}$, Chien-Hong Lail, Tsung-Han Wul, \\ Pei-Hung Chang1, Yueh-Shih Chang1, Yii-Jenq Lan1 \\ ${ }^{1}$ Chang Gung Memorial Hospital, Clinic of Internal Medicine, Division of Hematology-Oncology, Keelung, Taiwan \\ ${ }^{2}$ Chang Gung Memorial Hospital, Clinic of Internal Medicine, Division of Hematology, Linkou, Taiwan \\ ${ }^{3}$ Chang Gung University Faculty of Medicine, School of Traditional Chinese Medicine, Taoyuan, Taiwan
}

\begin{abstract}
:
Dasatinib is a potent second-generation tyrosine kinase inhibitor for the treatment of chronic myeloid leukemia. The most common adverse event associated with dasatinib therapy is fluid retention, including pleural effusion. Dasatinib-related chylothorax has rarely been reported. The clinical manifestations, pathophysiology, management, and prognosis are not fully understood. Here we report a 40-year-old woman presenting with chylothorax following dasatinib use. We propose the hypothesis of its mechanism as well as offering a review of the relevant literature.
\end{abstract}

Key Words: Dasatinib, Chylothorax, Chronic myeloid leukemia

Özet:

Dasatinib kronik miyeloid lösemi tedavisinde kullanılan etkin bir ikinci kuşak tirozin kinaz inhibitörüdür. Dasatinib tedavisi ile ilişkili en sık görülen yan etki plevral effüzyonu da içeren sıvı retansiyonudur. Dasatinib ile ilişkili şilotoraks nadiren bildirilmiştir. Klinik belirtileri, patofizyolojisi, yönetimi ve prognozu tam olarak anlaşılamamıştır. Burada dasatinib kullanımı sonrasında şilotoraks gelişimi ile başvuran 40 yaşında bir kadın sunulmuştur. Dasatinib ile ilişkili şilotoraks gelişiminin mekanizmasının yanı sıra, konu ile ilgili literatür derlemesinden de bahsedilmektedir. Anahtar Sözcükler: Dasatinib, Şilotoraks, Kronik miyeloid lösemi

\section{Introduction}

Dasatinib (Sprycel ${ }^{\circledR}$ ) is a highly potent small-molecule inhibitor of BCR-ABL and Src family tyrosine kinases, which is indicated for the treatment of adults with newly diagnosed chronic-phase chronic myeloid leukemia (CML), resistance or intolerance to prior CML therapy, or Philadelphia chromosome-positive $(\mathrm{Ph}+)$ acute lymphoblastic leukemia (ALL). Pleural effusion was a common complication in 14\%$32 \%$ of all patients in clinical trials $[1,2,3]$. However, cases of dasatinib-related chylothorax have rarely been reported. The pathophysiology and management of chylothorax remain unclear. It is essential to provide more information about dasatinib-related chylothorax since dasatinib is increasingly being used due to its effectiveness in the treatment of CML and $\mathrm{Ph}+\mathrm{ALL}$.

\section{Case Presentation}

A 40-year-old female, a housewife, had been diagnosed with CML with b2a2 BCR-ABL fusion 8 years ago. The initial

Address for Correspondence: Yii-Jenq LAN, M.D.

Chang Gung Memorial Hospital, Clinic of Internal Medicine, Division of Hematology-Oncology, Keelung, Taiwan

Phone: +886-2-24329292 Ext. 2360 E-mail: liting@adm.cgmh.org.tw 
presentation was peripheral leukocytosis with splenomegaly. She received $400 \mathrm{mg}$ imatinib daily after the diagnosis and was titrated to $300 \mathrm{mg}$ twice a day due to slow log reduction of BCR-ABL after 2 years. The log reduction achieved major molecular response half a year later. Four years after the diagnosis, the treatment was shifted to $50 \mathrm{mg}$ of dasatinib twice a day because of intolerable knee pain. Her knee pain improved soon and the log reduction achieved complete molecular response (CMR) after 3 years of dasatinib treatment. Her liver and renal functions were monitored regularly and were within normal ranges.

Forty months after dasatinib use, the patient complained of progressive dyspnea and aggressive cough. Chest radiography revealed elevation of the right hemidiaphragm and small pleural effusion of the left (Figure 1A). Computed tomography (CT) confirmed prominent right pleural effusion and a small amount over the left side, as well as pericardial effusion. Echocardiography revealed adequate left ventricular function. Liver cirrhosis and splenomegaly were excluded by abdominal sonography. Ascites formation was excluded by the above CT and sonographic studies. Chest ultrasound-guided thoracentesis of bilateral pleural fluid yielded exudative effusion to be compared with her serum total protein concentration $(6.4 \mathrm{~g} / \mathrm{dL})$ and lactic dehydrogenase (LDH) concentration (244 U/L) (Table 1) according to Light's criteria [4]. Bilateral chylothorax was determined based on the milky yellow appearance and elevated triglyceride concentration (right: $263 \mathrm{mg} / \mathrm{dL}$, left: $536 \mathrm{mg} / \mathrm{dL}$ ) of the pleural effusion. Her serum triglyceride was $80 \mathrm{mg} / \mathrm{dL}$, similar to her previous levels. Culture was negative for bacteria and tuberculosis. Cytology of the pleural effusion showed lymphocytes and macrophage/mesothelial cells. The patient denied history of trauma or surgery. The etiologies of chylothorax including trauma, surgery, infection, or malignancy were not likely. Under the suspicion of drug-related chylothorax, dasatinib was discontinued. Diuretics and steroids were prescribed for symptom control. Her pleural effusion improved after 9 days of treatment (Figure 1B). Dasatinib was resumed 2 weeks after discontinuation and the pleural effusion recurred soon under the treatment of diuretics and steroids (Figure 1C). Due to intractable chylothorax even after repeated thoracentesis, dasatinib was discontinued again and the patient was later switched to nilotinib. The pleural effusion resolved gradually (Figure 1D). After several months of nilotinib use, no further symptoms of pleural effusion were experienced. Informed consent was obtained.

\section{Discussion and Review of the Literature}

Dasatinib (Sprycel ${ }^{\circledR}$ ) is a second-generation BCR-ABL tyrosine kinase inhibitor that targets most imatinib-resistant BCR-ABL mutations (except the T315I and F317V mutants) by distinctly binding to active and inactive ABL-kinase [5]. It was first used as second-line treatment for imatinib-resistant or -intolerant patients with CML [6]. Later, dasatinib was considered as first-line therapy for patients with CML, and further clinical trials are presently continuing [1]. Common adverse effects of dasatinib include body fluid retention (all grades, up to $35 \%$ ), skin rash (all grades, $10 \%$ to $20 \%$ ), and diarrhea (all grades, 3\% to 31\%) [7]. Among body fluid retention, pleural effusion was seen in 14\%-32\% of all patients in clinical trials of dasatinib [1,2,3]. The pathophysiology of dasatinib-related chylothorax is still not fully understood.

Chylothorax is caused by chyle leakage from the thoracic duct into the pleural space, which results from disruption or obstruction of the thoracic duct. Chyle typically contains high levels of triglycerides and often has a turbid and milky appearance. Triglyceride concentrations of pleural effusion greater than $110 \mathrm{mg} / \mathrm{dL}(1.24 \mathrm{mmol} / \mathrm{L})$ strongly support the diagnosis [8]. In this case, the patient's triglyceride concentration levels were $536 \mathrm{mg} / \mathrm{dL}$ in the left pleural space and $263 \mathrm{mg} / \mathrm{dL}$ in the right. Those findings supported the diagnosis of bilateral chylothorax. The most common etiology of chylothorax is surgery or trauma [9], accounting

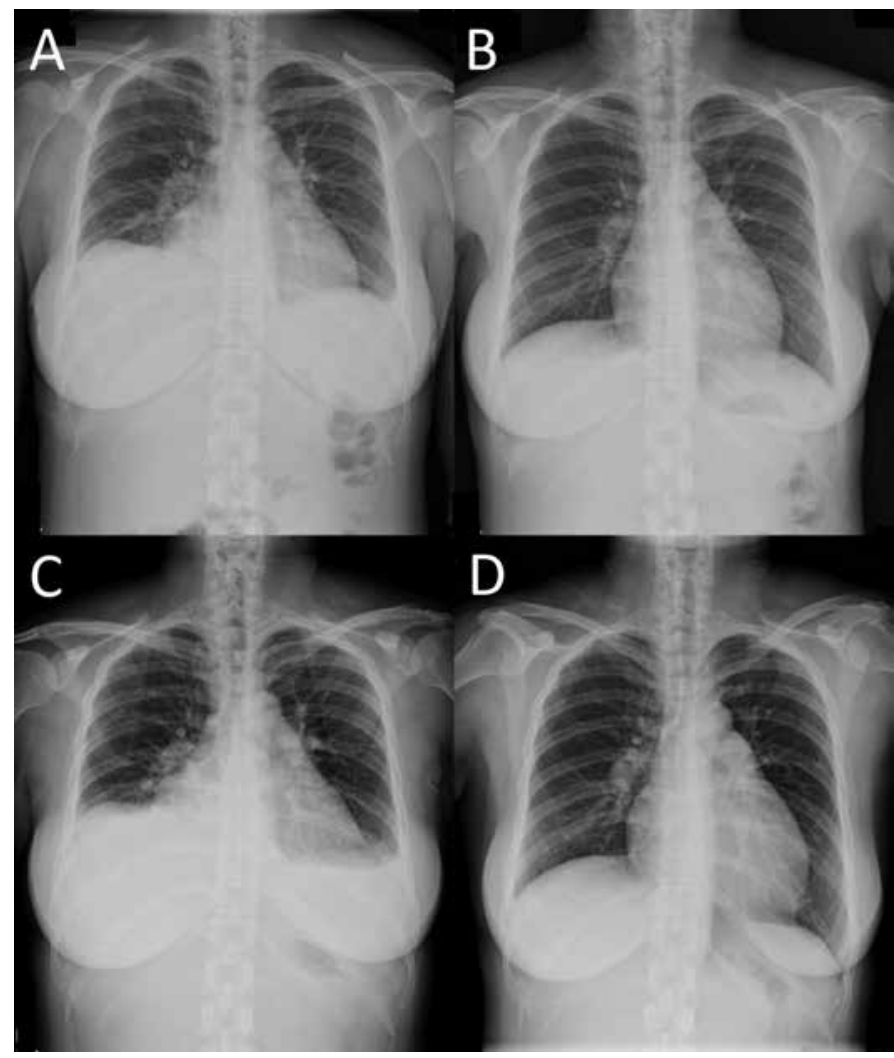

Figure 1. Chest radiography: A) initial small pleural effusion; B) 9 days later after diuretics and steroid treatment; C) recurrent pleural effusion after dasatinib was resumed; D) 6 weeks after dasatinib interruption. 
Table 1. Pleural effusion studies.

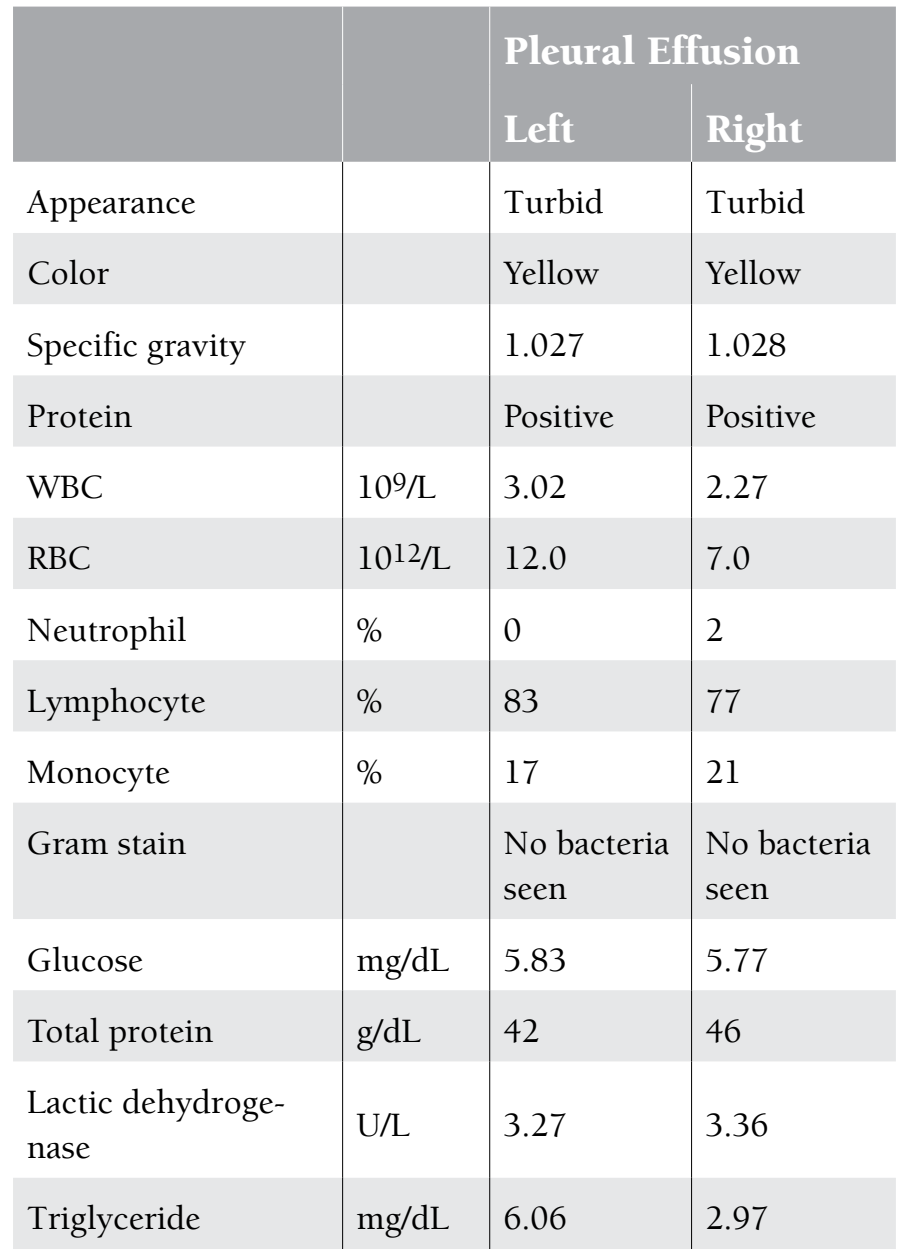

for nearly half of all cases. Nontraumatic etiologies include malignancy, sarcoidosis, retrosternal goiter, amyloidosis, superior vena cava thrombosis, benign tumors, congenital duct abnormalities, and diseases of the lymph vessels such as yellow nail syndrome, lymphangioleiomyomatosis, and hemangiomatosis [10]. Hematologic malignancies including lymphoma, chronic lymphocytic leukemia, and Waldenström macroglobulinemia were reported to be associated with chylothorax $[11,12,13,14,15]$. Among the above hematologic malignancies, non-Hodgkin's lymphoma is the most common. Only one case report mentioned CML and chylothorax, which was Adams-Oliver syndrome-related [16]. There is no current evidence of the association between the natural course of CML and chylothorax. In our case, the patient's pleural effusion was regarded as concordant exudate according to an analysis of chylothorax [17]. The causes of this kind of chylothorax include lymphoma, tuberculosis, empyema, and idiopathic/ biliopleural fistula. Infection was not likely as the culture results for tuberculosis and bacteria were negative. There was no evidence of lymphoma. It is most likely that the cause of the chylothorax was dasatinib therapy.
Dasatinib-related pleural effusions are generally lymphocyte-predominant exudates [18]. These findings suggest that the etiology of pleural effusions is different from that of body fluid retention. The exact mechanism of pleural effusions remains unclear. The possible mechanisms potentially include inhibiting platelet-derived growth factor receptor beta (PDGFR- $\beta$ ) expressed in pericytes, which is involved in the regulation of angiogenesis [19]. The defect of PDGFR- $\beta$ is associated with the formation of abnormal initial lymphatics in human lymphedema distichiasis, whereas another report suggested that platelet-derived growth factor (PDGF)-BB and its receptor, PDGFR- $\beta$, are directly lymphangiogenic $[20,21]$. This mechanism was reported in Gorham's disease-related chylothorax [22].

Src kinase inhibition by dasatinib is also possibly related to changes of vascular endothelial growth factor-mediated vascular permeability and stability of the pleural epithelium $[23,24]$. The PDGF-signaling pathway stimulates tumor cell proliferation, angiogenesis, and pericyte recruitment to tumor blood vessels. Furthermore, ligated integrins recruit several nonreceptor tyrosine kinases, including focal adhesion kinase, integrin-linked kinase, and Src-family kinases, among others [25]. In congenital chylothorax of human fetuses, human integrin defect genes were found [26]. If the presentation of Src kinases changes, it may lead to defects of integrin and further chylothorax.

The management of dasatinib-related pleural effusion including diuretics and a short course of prednisone $(40 \mathrm{mg}$ daily for 4 days) was suggested [18]. Once-daily dosing would reduce incidence of pleural effusions versus twice-daily dosing. There is no established standard treatment for chylothorax. In an earlier report, 138 patients were treated with dasatinib as second-line treatment after imatinib failure [27]. Fortyeight patients had pleural effusion and 1 of them developed recurrent chylous effusions, which required 12 treatments of thoracentesis. In another report, 40 patients were treated with dasatinib and 6 of them had pleural effusion [28]. One patient had right-sided chylothorax after about 1 year of dasatinib treatment and improved after drug interruption. In our case, the patient was treated with thoracentesis, prednisolone, and diuretics first, but the pleural effusions recurred soon after dasatinib was resumed. The second disappearance of chylothorax after discontinuing dasatinib again suggests the association between dasatinib and chylothorax. We therefore changed her treatment to another tyrosine kinase inhibitor, nilotinib. Now she maintains her CMR status.

In conclusion, in patients under dasatinib treatment who develop chylothorax, dasatinib-related chylothorax should be considered. Dasatinib should be discontinued if the chylothorax is intractable. Further investigation to define the 
pathogenesis of dasatinib-related chylothorax is warranted since dasatinib is increasingly being used.

\section{Conflict of Interest Statement}

The authors of this paper have no conflicts of interest, including specific financial interests, relationships, and/or affiliations relevant to the subject matter or materials included.

\section{Acknowledgment}

The authors thank all the members of the Cancer Center, Chang Gung Memorial Hospital, Keelung, for their invaluable help.

\section{References}

1. Kantarjian HM, Shah NP, Cortes JE, Baccarani M, Agarwal MB, Undurraga MS, Wang J, Ipiña JJ, Kim DW, Ogura M, Pavlovsky C, Junghanss C, Milone JH, Nicolini FE, Robak T, Van Droogenbroeck J, Vellenga E, Bradley-Garelik MB, Zhu C, Hochhaus A. Dasatinib or imatinib in newly diagnosed chronic-phase chronic myeloid leukemia: 2-year followup from a randomized phase 3 trial (DASISION). Blood 2012;119:1123-1129.

2. Porkka K, Khoury HJ, Paquette RL, Matloub Y, Sinha R, Cortes JE. Dasatinib $100 \mathrm{mg}$ once daily minimizes the occurrence of pleural effusion in patients with chronic myeloid leukemia in chronic phase and efficacy is unaffected in patients who develop pleural effusion. Cancer 2010;116:377-386.

3. Lilly MB, Ottmann OG, Shah NP, Larson RA, Reiffers JJ, Ehninger G, Müller MC, Charbonnier A, Bullorsky E, Dombret H, Brigid Bradley-Garelik M, Zhu C, Martinelli G. Dasatinib $140 \mathrm{mg}$ once daily versus $70 \mathrm{mg}$ twice daily in patients with Ph-positive acute lymphoblastic leukemia who failed imatinib: results from a phase 3 study. Am J Hematol 2010;85:164-170.

4. Light RW, Macgregor MI, Luchsinger PC, Ball WC Jr. Pleural effusions: the diagnostic separation of transudates and exudates. Ann Intern Med 1972;77:507-513.

5. Keam SJ. Dasatinib: in chronic myeloid leukemia and Philadelphia chromosome-positive acute lymphoblastic leukemia. BioDrugs 2008;22:59-69.

6. Abbott BL. Dasatinib: from treatment of imatinib-resistant or -intolerant patients with chronic myeloid leukemia to treatment of patients with newly diagnosed chronic phase chronic myeloid leukemia. Clin Ther 2012;34:272-281.

7. Bristol-Myers Squibb. Product Information: SPRYCEL(R) Oral Tablets, Dasatinib Oral Tablets. Princeton, NJ, USA, BristolMyers Squibb, 2010.

8. McGrath EE, Blades Z, Anderson PB. Chylothorax: aetiology, diagnosis and therapeutic options. Respir Med 2010;104:1-8.

9. Doerr $\mathrm{CH}$, Allen MS, Nichols FC 3rd, Ryu JH. Etiology of chylothorax in 203 patients. Mayo Clin Proc 2005;80:867-870.
10. STI571 Prospective International Randomized Trial (SPIRIT 2). Available at http://www.spirit-cml.org/spirit-2-home.aspx; accessed 24 August 2012.

11. Doerr CH, Staats BA, Markovic SN. Chylothorax in chronic lymphocytic leukemia patient. Am J Hematol 2002;70:237240.

12. Scholz GA, Sirbu H, Semrau S, Anders K, Mackensen A, Spriewald BM. Persisting right-sided chylothorax in a patient with chronic lymphocytic leukemia: a case report. J Med Case Rep 2011;5:492.

13. Thomas LC, Maida MJ, Martinez-Outschoorn U, FilickoO'Hara J, Morris GJ. Chronic lymphocytic leukemia/small lymphocytic lymphoma with pancytopenia and chylothorax. Semin Oncol 2011;38:165-170.

14. Rizzo S, Campagnoli M. Chylothorax as a complication of Waldenström's disease. Eur J Respir Dis 1984;65:371-372.

15. Antón Aranda E. Chylothorax complicating Waldenström macroglobulinemia. Arch Bronconeumol 2001;37:155-156 (article in Spanish).

16. Farrell SA, Warda LJ, LaFlair P, Szymonowicz W. Adams-Oliver syndrome: a case with juvenile chronic myelogenous leukemia and chylothorax. Am J Med Genet 1993;47:1175-1179.

17. Agrawal V, Doelken P, Sahn SA. Pleural fluid analysis in chylous pleural effusion. Chest 2008;133:1436-1441.

18. Brixey AG, Light RW. Pleural effusions due to dasatinib. Curr Opin Pulm Med 2010;16:351-356.

19. Bergers G, Song S, Meyer-Morse N, Bergsland E, Hanahan D. Benefits of targeting both pericytes and endothelial cells in the tumor vasculature with kinase inhibitors. J Clin Invest 2003;111:1287-1295.

20. Petrova TV, Karpanen T, Norrmén C, Mellor R, Tamakoshi T, Finegold D, Ferrell R, Kerjaschki D, Mortimer P, Ylä-Herttuala S, Miura N, Alitalo K. Defective valves and abnormal mural cell recruitment underlie lymphatic vascular failure in lymphedema distichiasis. Nat Med 2004;10:974-981.

21. Cao R, Björndahl MA, Religa P, Clasper S, Garvin S, Galter D, Meister B, Ikomi F, Tritsaris K, Dissing S, Ohhashi T, Jackson DG, Cao Y. PDGF-BB induces intratumoral lymphangiogenesis and promotes lymphatic metastasis. Cancer Cell 2004;6:333345.

22. Mavrogenis AF, Zambirinis CP, Dimitriadis PA, Tsakanikas A, Papagelopoulos PJ. Gorham-Stout disease. J Surg Orthop Adv 2010;19:85-90.

23. Breccia M, Alimena G. Pleural/pericardic effusions during dasatinib treatment: incidence, management and risk factors associated to their development. Expert Opin Drug Saf 2010;9:713-721. 
24. Carragher NO, Westhoff MA, Fincham VJ, Schaller MD, Frame MC. A novel role for FAK as a protease-targeting adaptor protein: regulation by p42 ERK and Src. Curr Biol 2003; 13:1442-1450.

25. Legate KR, Fassler R. Mechanisms that regulate adaptor binding to beta-integrin cytoplasmic tails. J Cell Sci 2009;122:187-198.

26. Ma GC, Liu CS, Chang SP, Yeh KT, Ke YY, Chen TH, Wang BB, Kuo SJ, Shih JC, Chen M. A recurrent ITGA9 missense mutation in human fetuses with severe chylothorax: possible correlation with poor response to fetal therapy. Prenat Diagn 2008;28:1057-1063.
27. Quintás-Cardama A, Kantarjian H, O’Brien S, Borthakur G, Bruzzi J, Munden R, Cortes J. Pleural effusion in patients with chronic myelogenous leukemia treated with dasatinib after imatinib failure. J Clin Oncol 2007;25:3908-3914.

28. Bergeron A, Réa D, Levy V, Picard C, Meignin V, Tamburini J, Bruzzoni-Giovanelli H, Calvo F, Tazi A, Rousselot P. Lung abnormalities after dasatinib treatment for chronic myeloid leukemia: a case series. Am J Respir Crit Care Med 2007;176:814-818 